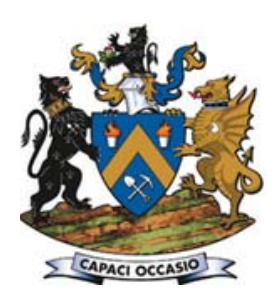

Affiliation:

${ }^{1}$ Tshwane University of Technology, Pretoria, South Africa ${ }^{2} \mathrm{CSIR}$, Pretoria, South Africa ${ }^{3}$ University of Johannesburg, South Africa

Correspondence to: S. Pityana

Email:

SPityana@csir.co.za

Dates:

Received: 31 May 2016

Revised: 21 Feb. 2018

Accepted: 14 Nov. 2018

Published: April 2019

\section{How to cite:}

Pityana, S.L., Baloyi, N., Tlotleng, M., and Popoola, P. Laser surface deposition of niobium and titanium-niobium on Ti6A14V substrates for biomedical applications. The Southern African Insitute of Mining and Metallurgy.

\section{DOI ID:}

http://dx.doi.org/10.17159/24119717/16/211/2019

ORCID ID: https://orchid.org/0000-00029273-2043

\title{
Laser surface deposition of niobium and titanium-niobium on Ti6A14V substrates for biomedical applications
}

\author{
S.L. Pityana ${ }^{1,2}$, N. Baloyi ${ }^{1}$, M. Tlotleng ${ }^{2,3}$, and P. Popoola ${ }^{1}$
}

\section{Synopsis}

The advantages of using $\mathrm{Nb}$ and $\mathrm{Ti}-\mathrm{Nb}$ coatings for improving the hardness and corrosion resistance of Ti6Al4V were investigated. It has been reported that Ti6Al4V used in orthopaedic implants tends to release toxic $\mathrm{Al}$ and $\mathrm{V}$ ions into the surrounding tissue. Thin layers of $\mathrm{Nb}$ and $\mathrm{Ti}-\mathrm{Nb}$ were deposited on Ti6Al4V substrates using a laser metal deposition technique. The deposited material was analysed using optical microscopy, scanning electron microscopy coupled with energy dispersive spectroscopy, and X-ray diffraction. The corrosion behaviour of the deposited layers was investigated using a Metrohm Autolab PG Stat101 compact potentiostat at $25^{\circ} \mathrm{C}$ in simulated body fluid. A Vickers hardness system was used to study the mechanical properties. Both $\mathrm{Nb}$ and $\mathrm{Ti}-\mathrm{Nb}$ coatings exhibited good metallurgical bonding with the substrate. The microstructure and the XRD analyses for the Nb system showed that the $\alpha$-Nb phase was most dominant, while the Ti-Nb system comprised a mixture of the $\alpha$ and $\beta$ phases. The average hardness of the Ti6Al4V substrate was $350 \mathrm{HV}_{0.3}$, with a slight increase for the $\mathrm{Nb}$ coating $\left(363 \mathrm{HV}_{0.3}\right)$ and a much higher hardness from the $\mathrm{Ti}-\mathrm{Nb}$ coating at $423 \mathrm{HV}_{0.3 .}$. The corrosion results show that the deposited $\mathrm{Nb}$ was more corrosion-resistant in the solution than either the Ti6Al4V substrate or the Ti-Nb coating.

\section{Keywords}

Corrosion, laser surface deposition, niobium (Nb), titanium (Ti), titanium-niobium (Ti-Nb), Ti6Al4V.

\section{Introduction}

Metals such as CoCrMo, 316L stainless steel, and NiTi alloy are used for manufacturing biomedical implants because of their distinct properties, including low Young's modulus and resistance to corrosion (Ryan, Pandit, and Apatsidis, 2006). These implants are required to remain in the body of the patient for many years. Due to a favourable combination of mechanical and corrosion properties, titanium (Ti) and its alloys have emerged as the material of choice for biomedical implants. Nevertheless, their use is not entirely without challenges. For example, in total hip replacement, surface degradation and release of metal debris from metal erosion caused by friction limit the service life of the implant (Oldani and Dominguez, 2012; Manivasagam, Dhinasekaran, and Rajamanickam, 2010). Ti6Al4V is generally regarded as the material of choice, but it has been found that over extended periods of time, the combination of surface corrosion and erosion releases toxic aluminium (Al) and vanadium (V) ions into the body (Khan, Williams, and Williams, 1996). This has led to the investigation of titanium alloys containing niobium (Nb), zirconium (Zr), tantalum (Ta), and molybdenum (Mo) as substitutes for the aluminium- and vanadium-containing Ti6Al4V (Okazaki et al., 1997).

The objective of this work is not to alter the mechanical properties of Ti6Al4V, but rather to improve its surface properties by deposition of a biocompatible layer with improved wear resistance when subjected to friction. It is known that the titanium matrix can be stabilized as the $\alpha$-Ti (hcp) or $\beta-\operatorname{Ti}$ (bcc) phase, depending on the element used; and it is acknowledged that alpha and beta alloys have different mechanical properties (Petrzhik, 2013). According to Rosenberg, Starosvetsky, and Gotman (2003), Zorn et al., (2005), and Godly, Starosvetsky, and Gotman (2004), Nb alloys are noteworthy due to their remarkably low elastic modulus, excellent corrosion resistance, and the presence of a metastable $\beta$ phase when dissolved in the Ti structure (Oldani and Dominguez, 2012; Kuphasuk et al., 2001). As a result, the $\beta$ - $\mathrm{Nb}$ phase has a higher hardness than Ti6Al4V. This $\beta$-Nb phase is also useful as it creates a passive layer when exposed to a corrosive environment such as body fluid (Kuphasuk et al., 2001; Lee, Ju, and Chern Lin, 2002).

In this work, $\mathrm{Nb}$ and a mixture of $\mathrm{Nb}$ and Ti were investigated as surface coatings on a Ti6Al4V substrate. Thin layers of $\mathrm{Nb}$ and $\mathrm{Ti}-\mathrm{Nb}$ were deposited on Ti6Al4V substrates using a laser deposition technique. The corrosion behaviour of the coatings was determined in a simulated body fluid (SBF) environment using a Metrohm Autolab PG Stat101 compact potentiostat at $25^{\circ} \mathrm{C}$. 


\section{Laser surface deposition of niobium and titanium-niobium on Ti6A14V substrates}

\begin{tabular}{|c|c|c|c|c|c|c|c|}
\hline \multicolumn{8}{|l|}{$\begin{array}{l}\text { Table I } \\
\text { Powder sp }\end{array}$} \\
\hline Type of alloy & PSD ( $\mu \mathrm{m})$ & $\begin{array}{l}\text { Composition } \\
\text { (wt\% Nb) }\end{array}$ & Power (kW) & $\mathrm{SS}\left(\mathrm{mm} \cdot \mathrm{s}^{-1}\right)$ & $B D^{*}(\mathrm{~mm})$ & $\mathrm{PFR}^{\star}\left(r \cdot \mathrm{min}^{-1}\right)$ & $\begin{array}{l}\text { Carrier gas flow } \\
(\text { L.min'-1) }\end{array}$ \\
\hline $\mathrm{Nb}$ & $210-10$ & 100 & $0.5,1.0,1.2$ & 9 & 4 & 3 & 5 \\
\hline $\mathrm{Ti}-\mathrm{Nb}$ & $350-10$ & $87-13$ & $1.0,1.2,1.5$ & 9 & 4 & 3 & 5 \\
\hline
\end{tabular}

* PSD: particle size distribution; SS: scanning speed; BD: beam diameter; PFR: power feed-rate

\section{Experimental set-up}

\section{Laser deposition}

A Rofin Sinar DY044, CW Nd:YAG laser system incorporating a three-way nozzle was used for the deposition. The laser head, mounted on a Kuka robot arm, was set at a standoff distance of $12 \mathrm{~mm}$ above the substrate. The laser beam spot and the scanning speed were kept constant at $4 \mathrm{~mm}$ and $9 \mathrm{~mm} . \mathrm{s}^{-1}$, respectively. $\mathrm{Nb}$ was deposited on Ti6Al4V using laser beam powers of 500,1000, and $1200 \mathrm{~W}$. Similarly, the laser beam power used for depositing Ti-Nb was 1000, 1200, and 1500 W. In order to prevent oxidation, the process was conducted in a rectangular container which was covered and purged with argon gas at $5 \mathrm{~L} \cdot \mathrm{min}^{-1}$. The process parameters used in these experiments are summarized in Table I.

\section{Material preparation and characterization}

Single and multiple tracks of $\mathrm{Nb}$ and $\mathrm{Ti}+\mathrm{Nb}$ were laser-deposited onto the surface of Ti6Al4V. The Nb powder had a mean particle size $\left(d_{50}\right)$ of $100 \mu \mathrm{m}$. The Ti-Nb powder was obtained by mechanical mixing and pre-alloying of elemental Ti and $\mathrm{Nb}$ powders, using a Restch PM 400M ball mill. The particle size range of the pre-alloyed Ti-Nb powder was $10-50 \mu \mathrm{m}$. Ti6Al4V substrate specimens, with dimensions of $30 \times 30 \times 8 \mathrm{~mm}$, were sandblasted and cleaned with acetone prior to the laser metal deposition process.

After deposition, the samples were sectioned in the transverse direction through the deposited layer for phase and microstructure analyses. The sectioned samples were mechanically polished and etched with either Keller's ( $\mathrm{Nb}$ coatings) or Kroll's (Ti-Nb coatings) reagents. The microstructures of the $\mathrm{Nb}$ and $\mathrm{Ti}-\mathrm{Nb}$ layers were examined by optical microscopy and scanning electron microscopy (SEM) using a JOEL instrument, and the chemical composition was analysed by SEM using energy dispersive X-ray spectroscopy (EDX). The microhardness of the layers was measured using a Matsuzawa Vickers hardness tester with a load of $300 \mathrm{~g}$ at intervals of $100 \mu \mathrm{m}$ from the top of the cladding to the claddingsubstrate interface.
Phase analyses of the clad layers were performed by X-ray diffraction (XRD) at $40 \mathrm{kV}$ and $30 \mathrm{~mA}$. X-ray crystallography was performed using a Ni-filtered $\mathrm{Cu} \mathrm{K}$ radiation source. Their matching phases were identified with the characteristic peaks of those in the files of the Joint Committee on Powder Diffraction Standards (JCPDS) references (JCPDS, 1995).

Polarization and qualitative electrochemical impedance spectroscopy measurements on the coated surfaces were carried out in $50 \mathrm{ml}$ of Hanks solution at room temperature (approx. $25^{\circ} \mathrm{C}$ ) using a Metrohm Autolab PG Stat 101 compact potentiostat, consisting of a three-electrode cell: a saturated calomel electrode $\left(\mathrm{Hg} / \mathrm{Hg}_{2} \mathrm{Cl}_{2}\right)$ in saturated $\mathrm{KCl}$ as the reference electrode and platinum as the counter-electrode. The samples were placed in a glass cell and a sample area of approximately $1.1 \mathrm{~cm}^{2}$ was exposed to the electrolyte. The system was interfaced with a computer to determine the open circuit potential (OCP). The anodic and cathodic Tafel plots were recorded using NOVA software.

\section{Results and discussion}

\section{Optical and scanning microscopy}

The microstructures of typical single-layer $\mathrm{Nb}$ and $\mathrm{Ti}-\mathrm{Nb}$ coatings produced by the laser deposition process on Ti6Al4V substrates are shown in the optical images in Figure 1. The images show that the deposited layers had bonded well with the substrate metal and formed coatings. The metallurgical interaction between the coatings and the substrate is more visible in the case of the $\mathrm{Ti}-\mathrm{Nb}$ coating, which displays a pronounced dilution region as shown by the arrow in Figure 1b. The large, visible pores in the coatings are thought to be due to vaporization of the coating material. Of note is the good metallurgical bond between the cladding and the substrate.

Figure 2 shows optical micrographs of the cross-sections of the thin Nb layers deposited on the Ti6Al4V substrate at laser powers of $500 \mathrm{~W}, 1000 \mathrm{~W}$, and $1200 \mathrm{~W}$. The images indicate the presence of honeycomb structures at $500 \mathrm{~W}$, a mixture of honeycomb and needle-like structures at $1000 \mathrm{~W}$, and needle-like structures at $1200 \mathrm{~W}$.

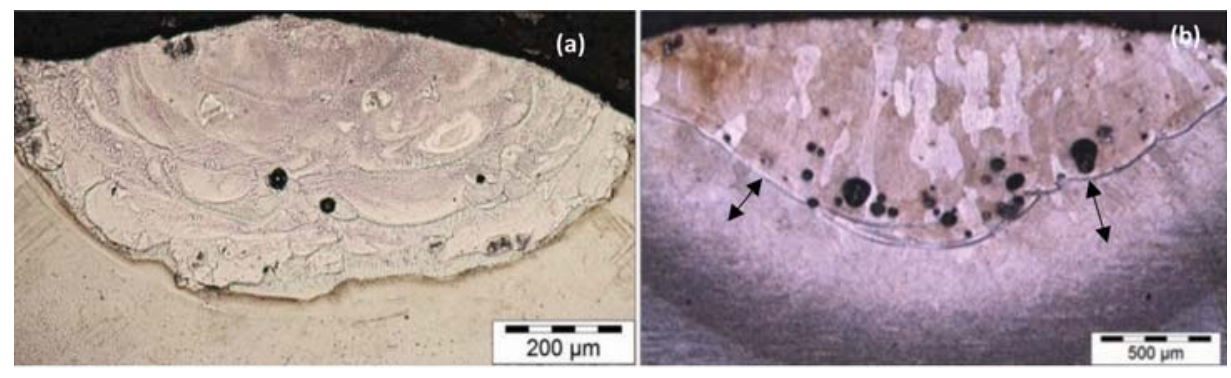

Figure 1-Typical single laser-deposited tracks of (a) $\mathrm{Nb}$ and (b) Ti-Nb coatings 


\section{Laser surface deposition of niobium and titanium-niobium on Ti6A14V substrates}

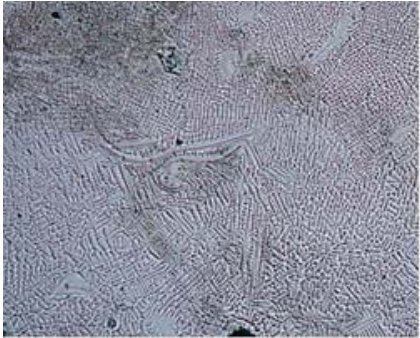

(a)

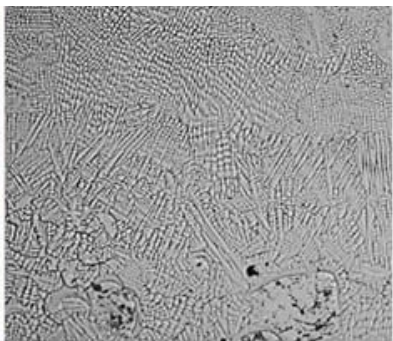

(b)

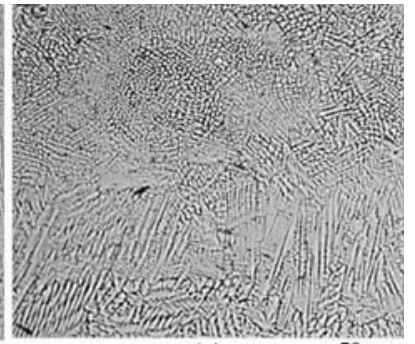

(c)

Figure 2-Cross-sections of Nb coatings deposited at (a) $500 \mathrm{~W}$, (b) $1000 \mathrm{~W}$, and (c) $1200 \mathrm{~W}$

Table II

EDX analysis (wt $\%$ ) of $\mathrm{Nb}$ coatings deposited at different laser powers

\begin{tabular}{|l|l|l|l|}
\hline Element & $\mathbf{5 0 0} \mathbf{W}$ & $\mathbf{1 0 0 0} \mathbf{W}$ & $\mathbf{1 2 0 0} \mathbf{W}$ \\
\hline $\mathbf{C}$ & 4.77 & 5.26 & 3.84 \\
\hline $\mathbf{O}$ & 2.31 & 1.83 & 1.71 \\
\hline $\mathbf{A l}$ & 1.86 & 1.88 & 2.14 \\
\hline $\mathbf{T i}$ & 27.87 & 33.09 & 41.65 \\
\hline $\mathbf{V}$ & 1.13 & 1.23 & 1.89 \\
\hline $\mathbf{N b}$ & 62.05 & 56.71 & 48.76 \\
\hline
\end{tabular}

Table II lists the compositions of the Nb coatings. The data indicates the effect of laser power on the dilution effect of $\mathrm{Nb}$ deposited coating in terms of $\mathrm{Nb}, \mathrm{Ti}, \mathrm{Al}$, and $\mathrm{V}$ content. At $500 \mathrm{~W}$ laser power, the $\mathrm{Nb}$ content is $62 \%$, decreasing markedly as the laser power increases. This decrease is attributed to increased dilution of $\mathrm{Nb}$ by the Ti matrix. The contents of $\mathrm{Al}$ and $\mathrm{V}$ remain within the range $1-2 \%$, which is lower than that of Ti6Al4V (substrate).

Figure 3 shows optical micrographs of the cross-sections of the Ti-Nb layers deposited at different laser powers. Due to the effect of pre-alloying $\mathrm{Nb}$ and $\mathrm{Ti}$, the microstructures obtained from this combination are fine and granular. The grain size varies with increasing laser power due to slow cooling.

Table III shows the EDX analyses of the Ti-Nb coatings deposited at different laser powers. The composition of the coating does not follow any trend with relation to change in laser power. The concentration of $\mathrm{Al}$ and $\mathrm{V}$ remained in the range $1.5-4 \%$, whereas the $\mathrm{Nb}$ content varied from $6.5 \%$ to $10 \%$.

\section{$X$-ray diffraction}

Figure 4 shows the XRD patterns of the $\mathrm{Nb}$ and $\mathrm{Ti}-\mathrm{Nb}$ coatings
Table III

EDX analysis (wt\%) of Ti-Nb coatings deposited at different laser powers

\begin{tabular}{|l|l|l|l|}
\hline Element & $1000 \mathrm{~W}$ & $1200 \mathrm{~W}$ & $1500 \mathrm{~W}$ \\
\hline $\mathrm{C}$ & 6.14 & 5.56 & 5.83 \\
\hline $\mathbf{O}$ & 4.35 & 4.37 & 5.13 \\
\hline $\mathrm{Al}$ & 3.34 & 3.91 & 3.09 \\
\hline $\mathrm{Ti}$ & 75.23 & 77.74 & 74.28 \\
\hline $\mathrm{V}$ & 1.98 & 1.81 & 1.41 \\
\hline $\mathrm{Nb}$ & 8.95 & 6.59 & 10.26 \\
\hline
\end{tabular}

deposited at various laser powers. There are no significant phase changes in either system when the laser power is increased. The pattern for Nb shows an orthorhombic $\left(\alpha^{\prime}\right)$ phase and a metastable $\beta$ phase. The $\alpha^{\prime}$ phase is attributed to the Ti6Al4V substrate; and the $\beta$ phase is due to the $\mathrm{Nb}$ in the melt pool. The XRD results for the Ti-Nb system also show the occurrence of hexagonal ( $\alpha$ ' '-Ti) phase and the presence of $\beta$ phase that seem to occur at the same angle for all the samples.

\section{Microhardness}

Microhardness profiles of the $\mathrm{Nb}$ and $\mathrm{Ti}-\mathrm{Nb}$ deposits are shown in Figure 5. Figure $5 \mathrm{a}$ represents $\mathrm{Nb}$ deposition at various powers. All the curves indicate that hardness increases from the top of the layer to the heat-affected zone (HAZ) and then decreases again towards the substrate. Figure $5 \mathrm{~b}$ depicts the profile for $\mathrm{Ti}-\mathrm{Nb}$ deposition at various powers. All the curves indicate a steady decrease in hardness value from the top of the cladding to the HAZ and the substrate. The average hardnesses of the deposited materials relative to the substrate are plotted in Figure 6. The $\mathrm{Nb}$ deposit has an average hardness of $363 \mathrm{HV}_{0.3}$ on the points taken on the deposited layer and $350 \mathrm{HV}_{0.3}$ closer to the substrate. The average hardness of the Ti-Nb deposit was 423

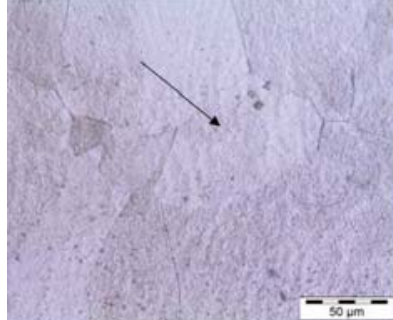

(a)

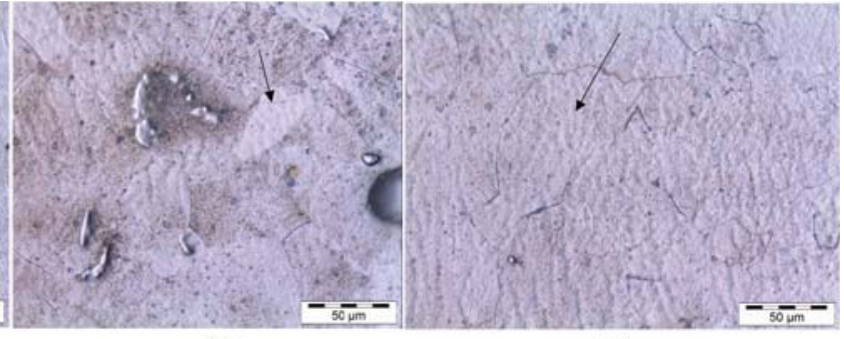

(b) (c)

Figure 3-Cross-sections of Ti-Nb coatings deposited at (a) $1000 \mathrm{~W}$, (b) $1200 \mathrm{~W}$, and (c) $1500 \mathrm{~W}$ 


\section{Laser surface deposition of niobium and titanium-niobium on Ti6A14V substrates}

$\mathrm{HV}_{0.3}$, the hardness of the layers gradually decreasing to that of the substrate. This trend was apparent in all the layers. In this system (Ti-Nb), a hardness improvement was observed and the hardness of the deposit was approximately $70 \mathrm{HV}_{0.3}$ higher than that of the substrate.

Figure 6 represents the microhardnesses of the materials. $\mathrm{Nb}$ coatings show variable hardness behaviour, with an average hardness of $364 \mathrm{HV}_{0.3}$. Ti-Nb coatings display a steady decrease in hardness, with depth Figure $5 b$ ), with an average hardness value of $423 \mathrm{HV}_{0.3}$. This indicates that Ti had a positive effect on the coatings, due to the presence of harder phases.

The increase in hardness value for $\mathrm{Nb}$ coatings was approximately $5 \%$, which is attributed to dilution of $\mathrm{Nb}$ by the substrate. The $8.4 \%$ increase in hardness for the Ti-Nb coatings is due to the presence of $a$-Ti, which results in a martensitic microstructure.

\section{Corrosion behaviour}

The potentiodynamic polarization curves of all the $\mathrm{Nb}$ coatings in simulated body fluid (Hanks solution) electrolyte, under a standard working environment are plotted in Figure 7. The results presented were selected because of the nearest mean values of the current densities, and they indicate constant behaviour, especially during the first five minutes of immersion. The Tafel calculations have been deduced from the available data and are reported in Table IV.

The joint polarization curves in Figure 7 and the results in Table IV illustrate that the $\mathrm{Nb}$ coatings have better corrosion properties than the Ti-Nb coatings and the substrates. It is also observed that the corrosion potential $\left(E_{\text {corr }}\right)$ of the Ti-Nb coating was slightly lower than that of the substrate (Table IV), while the $\mathrm{Nb}$ coating had the highest $E_{\text {corr }}, 0.709 \mathrm{~V}$ higher that of Ti-Nb.

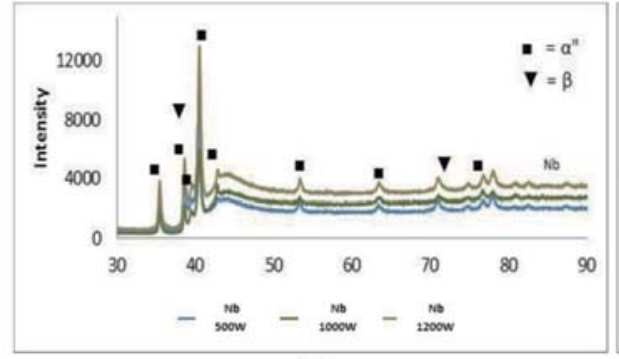

(a)

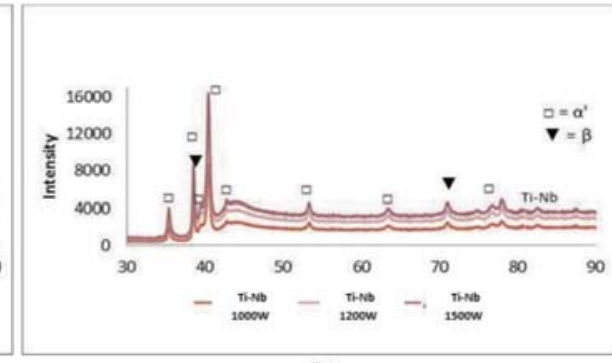

(b)

Figure 4-X-ray diffraction (XRD) patterns of laser-deposited (a) Nb and (b) Ti-Nb coatings

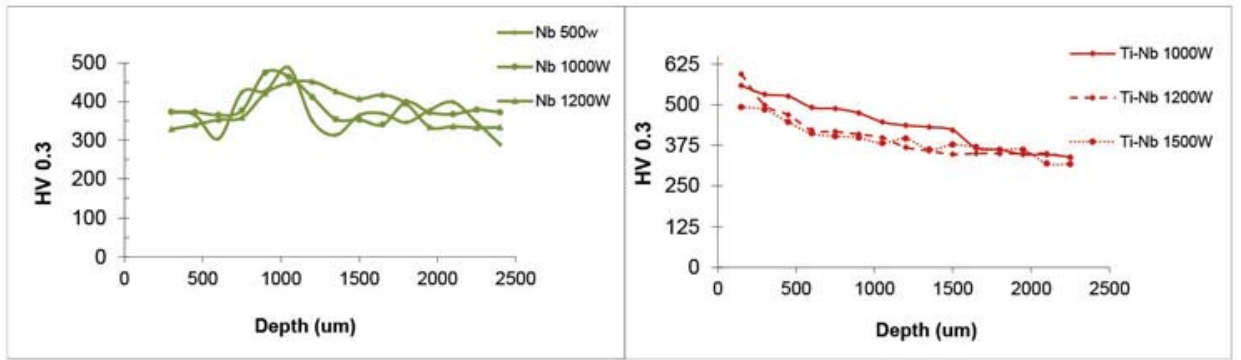

(a)

(b)

Figure 5-Hardness profiles measured from the edge of the coating. (a) $\mathrm{Nb}$ and (b) $\mathrm{Ti}-\mathrm{Nb}$

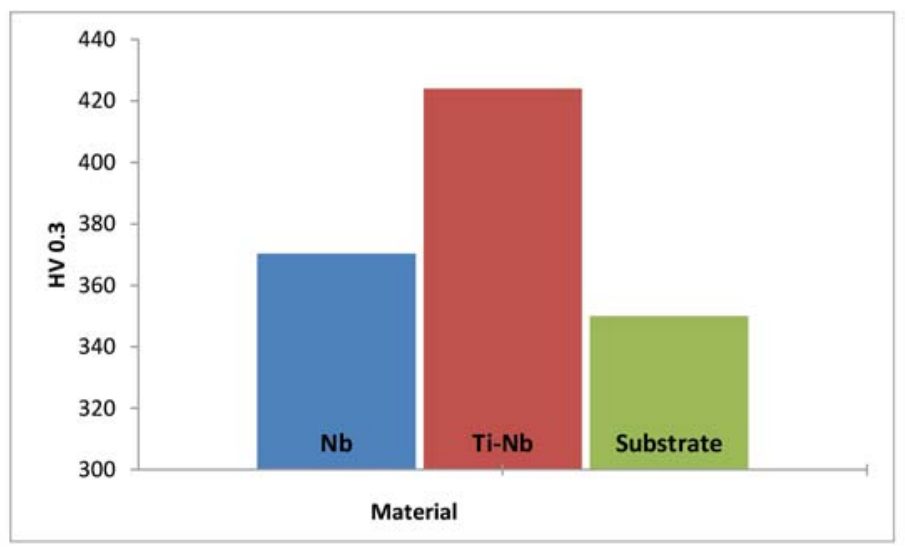

Figure 6-Average microhardness property plots for $\mathrm{Nb}$ and $\mathrm{Ti}-\mathrm{Nb}$ coatings 


\section{Laser surface deposition of niobium and titanium-niobium on Ti6A14V substrates}

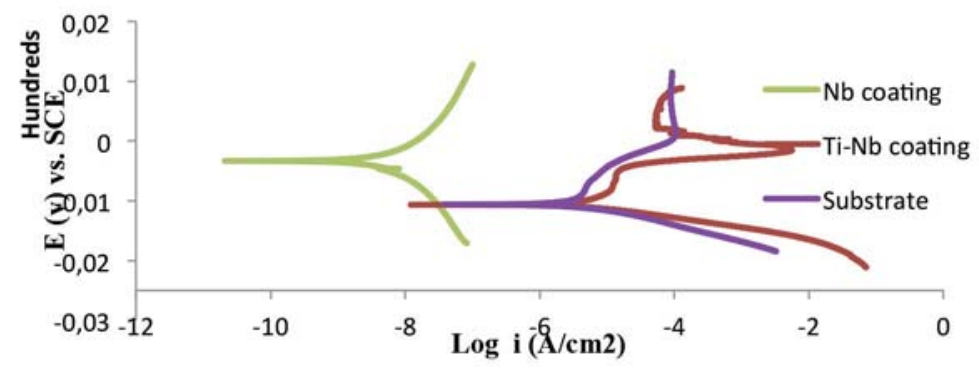

Figure 7-Potentiodynamic polarization curves of $\mathrm{Ti}-\mathrm{Nb}$ and $\mathrm{Nb}$ deposited onto Ti6Al4V after immersion in a Hanks solution electrolyte at the standard condition

The $\mathrm{Nb}$ coating also exhibits the lowest corrosion current density while the Ti-Nb coating and the substrate displayed similar $i_{\text {corr }}$ values in the same decade. This also indicates that the $\mathrm{Nb}$ coating is more corrosion-resistant.

According to Osorio et al., (2011), the corrosion resistance of alloys depends on the microstructure and the presence of defects. This was also observed in this study. The coatings with microstructures formed in the presence of oxide layers showed passivation behaviour and consequently mitigate against further corrosion. This is seen in the microstructures of the $\mathrm{Nb}$ coatings; the highest resistance to corrosion was exhibited where less dilution and fewer pores were present. Furthermore, these coatings had the lowest hardness due to the low Ti content. All these factors are connected to the latent heat of materials. During heating, niobium reacted with oxygen to form an oxide layer that is resistant to corrosion. Furthermore, the refractory nature of $\mathrm{Nb}$ also contributes to its corrosion resistance. Similar to $\mathrm{Nb}$, molten $\mathrm{Ti}(\mathrm{Ti}-\mathrm{Nb})$ would easily react with oxygen and form a passive $\mathrm{TiO}_{2}$ layer, which is also corrosion-resistant. This corrosion reaction of Ti-Nb seems to resemble that which occurs on Ti6Al4V surfaces when exposed to simulated body fluids, as explained by Mythili, et al., (2007). The overall performance of $\mathrm{Nb}$ surpassed that of $\mathrm{Ti}-\mathrm{Nb}$ and Ti6Al4V; irrespective of the passive layer and improved hardness due to the presence of $\mathrm{TiO}_{2}$, the $\mathrm{Nb}$ coating performed better in Hanks solution.

\section{Conclusions}

$\mathrm{Nb}$ and $\mathrm{Nb}$-Ti were successfully coated onto Ti-6Al-4V alloy substrates using laser deposition. The hardness and corrosion behaviour of the coatings were investigated, resulting in the following observations.

$>$ Ti-Nb deposited on the Ti6Al4V substrate resulted in a fine microstructure consisting of $\alpha^{\prime}$ and $\beta$ phases that have a higher hardness than that of the substrate. This alloy displayed a similar corrosion resistance to the Ti6Al4V substrate.

Nb deposited on the Ti6Al4V substrate resulted in a dendritic microstructure with an uneven hardness profile. The XRD pattern indicated the presence of the $\alpha$ ' orthorhombic phase, which is significantly more resistant to

\section{Table IV}

\section{Corrosion behaviour of the laser-deposited materials}

\begin{tabular}{|l|l|l|l|}
\hline Sample & $i_{\text {corr }}\left(\mathbf{A} / \mathbf{c m}^{2}\right)$ & $E_{\text {corr }}(\mathbf{V})$ & $\begin{array}{l}\text { Corrosion rate } \\
(\mathbf{m m} / \mathbf{a})\end{array}$ \\
\hline Substrate & $4.37 \mathrm{E}-07$ & -1.06 & $1.79 \mathrm{E}-02$ \\
\hline $\mathrm{Ti}-\mathrm{Nb}$ & $9.70 \mathrm{E}-07$ & -1.15 & $4.24 \mathrm{E}-03$ \\
\hline $\mathrm{Nb}$ & $1.30 \mathrm{E}-10$ & -0.33 & $2.16 \mathrm{E}-08$ \\
\hline
\end{tabular}

corrosion than the substrate and Ti-Nb layers.

> The high latent heat of $\mathrm{Nb}$ influences the dilution, microstructure, and hardness of the coating.

- Based on corrosion results alone, Nb-cladded Ti6Al4V will be a better option than $\mathrm{Ti}-\mathrm{Nb}$ as a coating to improve the surface properties of surgical implants.

\section{Acknowledgements}

This paper is based upon work supported financially by the National Research Foundation. The National Laser Centre, CSIR, Pretoria is thanked for use of the laser facility. Appreciation goes to the project initiators, Tshwane University of Technology, and to everyone who assisted with the analyses and interpretation of the results.

\section{References}

Godley, R., Starosvetsky, D., and Gotman, I. 2004. Bonelike apatite formation on niobium metal treated in aqueous NaOH. Journal of Materials Science: Materials in Medicine, vol. 15, no. 10. pp. 1073-1077.

JCPDS. 1995. Powder Diffraction File. Joint Committee on Powder Diffraction Standards (JCPDS)-International Centre for Diffraction Data (ICDD); Swarthmore, PA, USA: 1995. Card no. 44-1294.

KHAN, M.A., WilLiams, R.L., and Williams, D.F. 1996. In-vitro corrosion and wear of titanium alloys in the biological environment. Biomaterials, vol. 17, no. 22. pp. 2117-2126.

Kuphasuk, C., Oshida, Y., Andres, C.J., HovjJITRA, S.T., Barco, M.T., and Brown, D.T. 2001. Electrochemical corrosion of titanium and titanium-based alloys. Journal of Prosthetic Dentistry, vol. 85, no. 2. pp. 195-202.

LEE, C.M., Ju, C.P., and Chern Lin, J.H. 2002. Structure-property relationship of cast Ti-Nb alloys. Journal of Oral Rehabilitation, vol. 29, no. 4. pp. 314-322.

Manivasagam, G., Dhinasekaran, D., and Rajamanickam, A. 2010. Biomedical implants: corrosion and its prevention - a review. Recent Patents on Corrosion Science, 2010, no. 2. pp. 40-54. https://pdfs.semanticscholar.org/84c0/ a7dcb2a9f567e67ec847801410a6f097c2d2.pdf

Mythili, R., Shankar, A.R., Saroja, S., Raju, V.R., Vijayalakshmi, M., Dayal, R.K., and BalasuBRAmANIAM, R. 2007. Influence of microstructure on corrosion behavior of Ti- $5 \% \mathrm{Ta}-1.8 \% \mathrm{Nb}$ alloy. Journal of Materials Science, vol. 42 , no. 15. pp. 5924-5935.

ОкаZакі, Ү., Күо, К., Iто, Y., and Tateishi, T. 1997. Effects of Mo and Pd on corrosion resistance of V-free titanium alloys for medical implants. Materials Transactions, JIM, vol. 38, no. 4. pp. 344-352.

Oldani, C. and Dominguez, A. 2012. Titanium as a biomaterial for implants. Recent Advances in Arthroplasty. InTech. https://www.intechopen.com/books/recentadvances-in-arthroplasty/titanium-as-a-biomaterial-for-implants

Osorio, W.R., Mountinho, D.J., Peixoto. L.C., Ferreira, I.L., and Garcia, A. 2011. Macrosegregation and microstructure dendritic array affecting the electrochemical behavior of ternary Al-Cu-Si alloys. Electrochimica Acta, vol. 24. pp. 8412-8421.

Pетrzhiк, M. 2013. Dynamics of martensitic structure at TiNb-based quenched alloys under heating and loading. Journal of Physics: Conference Series, vol. 438, no. 1. p. 012020. IOP Publishing. http://iopscience.iop.org/ article/10.1088/1742-6596/438/1/012020

Rosenberg, R., StARosvetSKy, D., and Gotman, I. 2003. Surface modification of a low modulus Ti-Nb alloy for use in medical implants. Journal of Materials Science Letters, vol. 22, no. 1. pp. 29-32.

Ryan, G., PAndit, A., and Apatsidis, D.P. 2006. Fabrication methods of porous metals for use in orthopaedic applications. Biomaterials, vol. 27, no. 13. pp. 2651-2670.

Zorn, G., Gotman, I., Gutmanas, E.Y., Adadi, R., SaltrRa, G., and Sukenik, C.N. 2005. Surface modification of Ti45Nb alloy with an alkylphosphonic acid selfassembled monolayer. Chemistry of Materials, vol. 17, no. 16 . pp. 4218-4226. 